\title{
Why trust science in a trickster world of absolute contingency? The speculative force of mathematical abstraction
}

\author{
Elizabeth de Freitas \\ Manchester Metropolitan University \\ Corresponding Author: I.de-freitas@mmu.ac.uk
}

(Submitted: 4 May 2020; Accepted: 14 September 2020)

\begin{abstract}
This paper explores a set of dilemmas associated with relational ontologies in which contingency factors prominently, raising the methodological question: how should we come to know, and trust our knowledge of the world? I explore distrust in science and the limits of empiricism under chaotic climatic regimes and argue that a pluralist 'multiple earth' must include mathematical fabulation and other kinds of speculative abstraction.
\end{abstract}

Keywords: contingency, science, new materialism, speculative realism

\section{Introduction}

New materialisms pursue metamorphic couplings across conventional divides of mattermeaning, and they do so through both empirical and speculative techniques. It is this commitment to new forms of empiricism and speculation that interests me. In this paper, I dwell on the problematic but also productive tensions that arise in new materialist attempts to remix the physical and social sciences, attending to somewhat uncomfortable affinities with various kinds of philosophical naturalism and realism. I am interested in how empiricism depends on the very notion of relationality, and in how empiricisms might be pursued in various contemporary materialisms (agential, speculative, promiscuous, etc). Claims to relationality often entail an overreach of some kind, as Claire Colebrook suggests, calling out 'the implicit moralism of this posthuman relationality' which often seems intent on rescuing a humanity through spreading its relations, finding itself again and again in its monstrous inventions and its alienated others (2019a: 175). Celebrations of relationality can be rather selfserving ways of depoliticizing frictional encounters and failing to accept limits and incommensurables. Refusing to let being 'be' without relation is a way of colonizing the world with Humanist desire, part of the Kantian legacy of correlationism (Meillassoux, 2007). Thus, the fruitful nature of a term like relationality, and in particular the way it directs our attention to plasticity and processes of becoming, often belies the ways in which it is lived in radically disproportionate ways. 
I take Kyla Schuller's cautions (2018) that the capacity to be affected (the capacity to be 'in relation' and transformed ) is often associated with a Eurocentric sentimental biopower of 'impressibility', and that this biopower has been used to separate the 'sensitive' civilized from the abject other. And so, I am cautious and wary that new materialist emphasis on relational affectivity inherits 'the political legacies of liberal humanism ... [and may] unwittingly recapitulate the conceptual apparatus of the biopolitics of feeling' (Schuller, 2018: 11). I say this as someone who is nonetheless committed to the project of relational ontology. Insofar as new materialisms seek trans-intimacies that merge 'species' with/in environments, the risk of spreading white/fe/male/human 'familial feeling' further afield is always there, with the associated risks that such a project involves infecting other life with our violence, and potentially duplicating the oppression of state-sanctioned human relations (Barnes, 1997).

My focus here is on debates regarding trustworthy forms of empiricism. This paper explores how a new climatic regime complicates the nature of empirical science under posttruth conditions. I venture into this topic by exploring the power of speculative fiction to help us imagine and re-craft a form of empiricism adequate to pluralistic posthuman ecologies. In my keynote on this topic, at the $10^{\text {th }}$ Annual New Materialism conference, in Cape Town, South Africa, in December 2019, I explored this scenario by turning to works of speculative fiction $(\mathrm{SF})^{1}$. I referenced two works of fiction, The Three-Body Problem, by Cixin Liu and Annihilation by Jeff Vandermeer. Please see two recent publications, co-written with Sarah Truman, for detailed readings of these two novels, and a discussion of related ideas, (de Freitas and Truman, 2020a; de Freitas and Truman, 2020b). What follows here are excerpts from that keynote, focusing on science dis/trust and the role of speculative thought and abstraction in science. I follow many others in Science Studies who have taken up speculative fiction to think through the many pasts, presents and futures of science. Banu Subramanium (2014) has called for more engaging stories that track the interdisciplinary fissures of the sciences and the humanities; Aimee Bahng (2017) has argued that the science fiction of Octavia Butler should itself be considered a kind of Science Studies, for how it mobilizes 'speculative fabulation' to explore radical onto-epistemological modes of alien life, queer notions of kinship and decolonial reproduction.

Speculative fiction pursues the promiscuous power of the imagination to think otherwise, often breaking with the assumptions of contemporary science. Promiscuity is used here as a positive queering of conventions of practice, and a way of contesting ontological assumptions about the nature of matter. And yet, as Alexis Lothian (2018) reminds us, looking back at old European speculative fiction reveals that even justice-oriented authors whose aim was to use SF to 'halt and divert' various kinds of injustice, often crafted narratives that nonetheless supported heteronormative and white supremacist imaginaries (Lothian, 2018: 56). John Rieder (2008) similarly recounts the ways in which SF is invested in the human capacity for colonialism. Speculative thought is not innocent (Colebrook, 2019b). Kara Keeling (2019) explores in

\footnotetext{
${ }^{1}$ I would like to express my gratitude for the incredibly thoughtful and catalytic keynote response by Delphi Carstens.
} 
particular the difference between corporate speculative investments (serving extractive industries), and SF literature and film that operate through falsification and fantasy. She deploys various queer formulae to refuse the corporate imagined futures, and draws on Gilles Deleuze and Édouard Glissant, among others, to further cultivate a poetics of speculative thought. Inspired by this kind of work, my aim here is to open up some of the theoretical tensions, in post-truth conditions, between 'trusting that a particular scientific claim is true' and 'trusting in particular dependency relations', under a chaotic climatic regime.

\section{Science dis/trust}

Trust is a complex relation involving affective, cognitive, practical, emotional, and absurd facets. Public trust in science in the US has significantly diminished from the post-war days of naïve enthusiasm (Alumkal, 2017). Distrust of climate science in particular is correlated with libertarian free market advocates (Gauchat, 2012). Historian of science, Sven Ove Hannson defines science as 'the practice that provides us with the most reliable (i.e. epistemically most warranted) statements that can be made, at the time being, on subject matter covered by the community of knowledge disciplines' (2017: 63). But trust in science is far more complex than what seems to be suggested by such a definition (Funk et al, 2019). Many contemporary skeptics and denialists critique science today for its lack of certainty and its reliance on speculative mathematical theories (Oreskes, 2019; Pittinsky, 2015). Faulkner and Simpson in their 2017 book The Philosophy of Trust emphasize that trust involves dependence relations and an expectation that the trusted will see this dependence as a reason to act according to the expectation. In other words, there is an expectation on behalf of the trusting agent that the other will find it reasonable to engage in a trusting relationship. Thus, questions regarding science, such as 'should we trust a theory' or 'should we trust the mathematics, and therefore not worry about empirically testing the theory?' need to be considered not only in terms of epistemic reliability, but also in terms of the dependency relations and affective bonds and aesthetic investments that strongly constitute feelings of trust. The philosopher Robert Stern (2017) suggests that trust is not so much of our making as it is given in life itself, a public good that we cannot take credit for, in a world where affect and feelings of betrayal both fuel and destabilize our collaborations. Perhaps trust is basic to life in some fundamental way, being a capacity or tendency that belongs first and foremost to a relational ecology.

When trust is pronounced in a situation, and the stakes are high, feelings can move from disappointment to betrayal if that trust is broken. Latour (2018) suggests that the widespread 'epistemological delirium' that characterizes denial of climate science must be understood as an effect of betrayal, in that people have been denied the globe that was promised in the name of Modernism:

... this "people" has been coldly betrayed by those who have given up the idea of actually pursuing the modernization of the planet with everyone, because they [the elites] knew, before everyone else, that such modernization was impossible - precisely 
for want of a planet vast enough for their dreams of growth for all. Before accusing "the people" of no longer believing in anything, one ought to measure the effect of that overwhelming betrayal on people's level of trust. Trust has been abandoned along the wayside. (Latour, 2018: 22-23).

And yet Rutjens, et al. (2017) document how contemporary distrust in science in the US has emerged in different ways. The five key topics that elicit distrust are climate science, stem cell research, evolution, the Big Bang Theory, and nanotechnology (Blake, 2015). Although these five all draw from different reasons for that distrust, there are marked correlations. For instance, studies show that endorsement of a free-market ideology can reliably predict skepticism in the anthropogenic causes of climate change (Lewandowsky and Oberauer, 2016). The Union of Concerned Scientists and various speakers at the March for Science have declared that Christian right organizations are at war with science. Other political leaders interested only in free market economics further support these organizations (Mooney, 2005). However, a Nature editorial suggested that casting the current situation as a 'war on science' was too polarizing (Nature, 2017). In October 2018, President Trump told the Associated Press that he had "a natural instinct for science", intending to shore up his authority and undermine that of the scientific establishment. ${ }^{2}$

Education plays a complex role in science dis/trust. Studies show that further education does not necessarily alter beliefs about the trustworthiness of science (Drummond and Fischhoff, 2017). These studies found that taking a science course at college, perhaps as a mandatory course, is frequently used by the student to further support science distrust and does not necessarily cause students to embrace the scientific knowledge. Ironically, this research was based on data from national surveys whose questions actually entrench narrow images of science. In other words, multiple choice survey questions forced respondents to affirm or deny their trust, rather than allow for a more nuanced evaluation that might explore degrees of trust and the complex webbing of trust. ${ }^{3}$

In response to the current denialism of climate science, the US National Science Teachers Association (National Science Teaching Association 2018) published an official statement, offering support and guidance on how to teach climate science. Notably, the document points to the 'overwhelming scientific consensus' to support its position, declaring: 'The scientific consensus on the occurrence, causes, and consequences of climate change is both broad and deep' (Melillo, et al., 2014, n.p.). Claims to consensus are crucial in both establishing scientific truth within the community of scientists, but also in contesting the authority of science within the community of skeptics. Denialists are often seeking absolute truths, and are thus disappointed by, and indeed distrustful of, the consensus-making habits of scientists (Oreskes, 2019).

\footnotetext{
${ }^{2}$ Some scientists pointed out that a "natural instinct for science" was an oxymoronic claim.

${ }^{3}$ More recent surveys have aimed for more nuance (see Funk, et al., 2019)
} 
Scholarship in Science and Technology Studies (STS) has shown how scientists, like the rest of us, are opportunistic and biased, and often working in the service of sexism, racism, and colonialism. As Kathryn Yusoff (2018) explains, geological sciences, for example, have contributed to the climate crisis through their complicit partnership with corporate mining companies. For this and other reasons, she argues that there is no one humanity that suffers the Anthropocene, but a multiple earth of a billion black anthropocenes (Yusoff, 2018). Tsing (2015) and Haraway and many others turn to terms like Capitalocene, Anthrobcene, Plantationocene to bring this point home; important links between postcolonialism and climate make evident this impact (Chakrabarty, 2009, 2012, 2014). And yet to contest the 'we' of the Anthropocene altogether can, as we see with contemporary science denialists, further fuel a free market capitalism which benefits from continued inequity and continued corporate acquisition (Danowski and Viveiros de Castro, 2017). The term 'Climatic regime' reminds us that 'the climate' is never a pure state of nature operating outside of culture, but always populated and engendered by diverse agencies, some of them human (Verlie, 2017). I have explored these tensions in more detail elsewhere (de Freitas, 2019; de Freitas and Weaver, 2019; de Freitas and Truman, 2020a).

\section{The metamorphic zone}

Some new materialist theories advocate for an image of science as an activity that entails forming alliances with nonhuman agencies. Latour $(2017,2018)$ argues that science is one of our best pluralistic 'engendering' practices to be used as we investigate the complex agentic 'metamorphic zone' of the planet he calls 'Gaia'. He suggests that this 'multiple earth' has two fundamental features:

it is made of agents that are neither deanimated nor other animated, and it is made of agents that are not prematurely unified in a single acting whole. Indeed, the composition of Gaia is profoundly unknown, shaped by an infinity of heterogeneous agencies and waves of action that have the potential to defy globalism. This is Latour's multiple earth. (de Freitas, 2020: 206)

To the extent that new materialists embrace a Gaian earth that is a metamorphic creature with trickster capacities, these agentic powers are 'a property of the world itself and not only a phenomenon of language about the world' (Latour, 2017: 69, italics in original). Accordingly, science becomes - at best - an activity that increases pluralism, expanding the alliances, and ultimately assembling another more-than-human political body. As Shaviro also states, rather than treat matter as inert and passive, 'scientists work by negotiating with nonhuman entities, and by entering into alliances with them' (Shaviro, 2015: 11). Through such alliances, science actively populates the world with diverse non-human agencies (gluons, amoebas, gravitational waves, etc.), according to an immanent ontology that is no less realist for being thoroughly situated. 
The clear result of the scientific disciplines is an immense increase in what moves, acts, heats up, boils over, and becomes complicated-in sum, in what actually animates the agents that constitute the world and in the continuous refinement of the metamorphic zone that we encountered in the earlier lectures. (Latour, 2017: 163. italics in original)

If science is at its best when proliferating non-human agencies and remixing the metamorphic zone, how might it guard against a sentimentalism or biopolitics of feeling that imprints whiteness or humanity onto everything that was once alien or other? How should we trust science in a relational ontology characterized by this radical contingency and more-thanhuman agency? Since hierarchical power relations persist, a 'healthy scepticism' towards scientific claims must be considered part of the cosmic context in which a lawless real of absolute contingency might well characterize the milieu. Within such posthuman ecologies, we are called to keep front and centre the political nature of any pluralist science of dependency relations and "engendering" practices. And since speculative thought is the power horse behind such practices, we need to look a little closer at how such speculation works in science. In particular, we need to grapple with the links between speculation, abstraction, and modelling. Mathematical models have been the very instruments for furthering our understanding of climate change, and yet they are also global scale abstractions typically dislocated from the local. This dilemma concerns the distinctive capacities of mathematics, as both a delimiting force and a speculative invention, an act of abstraction and creative worlding, serving to both mis/represent the real and yet also to imagine otherwise (Sinclair, et al., 2013).

\section{Mathematical modeling}

Mackenzie Wark (2017) suspects Latour's approach is simply not well equipped to deal with the powerful role that mathematical models and simulations play in climate science: 'no amount of agential complexity or empirical complication really disturbs that big picture' (Wark, 2017: n.p.). Climate science models may be based in big data techniques, emerging from a constant feedback loop and stochastic training on massive amounts of data points, but they are nonetheless large-scale abstract models that take on a life of their own. Wark seems to think that Latour has banished the art of abstraction - banished the mathematics as bad abstraction, a reduction of complexity, a betrayal of immanence. In other words, Latour sacrifices the speculative power of abstract thought when he blames mathematics for serving 'the view from nowhere'. Indeed, I suspect we will need to think more creatively about mathematical abstraction as a generative activity (and not only as a reductive subtraction), a creative act that brings the new forth, making it part of the metamorphic zone where truth is contested. To be fair, Latour has written insightfully about the nature of the quantitative, inspired by the early posthumanist sociologist Gabriele Tarde, and shown how new tools in the digital humanities could be used to study complex science networks (Latour, 2010). This work, however, keeps the abstract or the 
speculative somewhat shackled, as it seeks potential applications of big data to the study of actor-networks.

There are other relational ontologies that incorporate a more speculative mathematics, but they often ascribe, problematically, to a 'naturalized metaphysics' and 'eliminative materialism' or 'physicalism'. These are typically scientistic in what is often called a form of "strong realism" and committed to the ultimate unity of science, and in some cases to an allencompassing theory of everything (ToE). For instance, James Ladyman and Don Ross (2007), in their book Everything Must Go, argue for a relational metaphysics that rests on homotopy type theory (a kind of mathematical logic) as the ontological foundation of the real. They ascribe to a total identity between physical and mathematical structures, calling the approach 'structural realism'. Their work presents the quintessential example of reductive formalisms. They are adamantly scientistic in their claim that 'scientific institutional processes are absolutely and exclusively authoritative' (Ladyman and Ross, 2007: 65). Ladyman and Ross suggest that their realism is not trapped in Kantian correlationism, because they believe that science can come to know reality as it is independent of us. This notion of 'independence' is at the heart of many disagreements between new materialists and realists, including speculative realists like Graham Harman (de Freitas, 2017). It is for this reason that I dwell on the notion of dependency relations within the metamorphic zone, or rather, on how dependency relations are what characterizes absolute contingency.

Foundational projects, like Ladyman and Ross's, are dangerous erasures of the plurality of practice, and might seem overly focused on epistemic truth-preserving procedures. Yes, they commit to a kind of relational ontology, and ontological realism, but their image of science is positivistic. Thinkers like Latour and Stengers (2018) might claim that Ladyman and Ross misrecognize science, because they fail to incorporate the efforts of science to fabulate within a metamorphic nature. For new materialists, being a part of the metamorphic zone is actually how science effectively procures knowledge of the real. lan James (2019), who attempts to walk a zig-zag path through all these thinkers, suggests that scientific realisms need a dose of insufficiency, modesty, and sympathy.

Mathematics plays an enigmatic role in debates regarding the authority of science. Scientific theories that seem to rely excessively on mathematical prowess are often considered overly speculative. At the 2015 Munich conference Why Trust a Theory? Reconsidering Scientific Methodology in Light of Modern Physics, Helga Kragh notes that 'the classical demarcation problem between science and non-science has taken a new turn with the appearance of fundamental and highly mathematical theories which may not be experimentally testable in the ordinary sense' (2015: n.p.). According to the physicist Sabine Hossenfelder (2018) in her book Lost in Math: How Physics is Led Astray by Beauty, physics has lost touch with the real because superstring theories and multiverse hypotheses are so caught up with mathematical objectives of naturalness and aesthetic balance. She suggests that physics is no longer physics but some kind of pure mathematical speculation, a kind of 'post-empirical physics', which is not to be trusted as a reliable description of the world. The philosopher Dudley Shapere states rather 
controversially that 'physics is in fact approaching, or perhaps has reached, the stage where we can proceed without the need to subject our further theories to empirical test' (2000: 149-161). But Kragh (2015) and others point out that non-empirical theory building in physics through speculative mathematics is not new.

\section{Speculative materialism}

I turn now to speculative fiction (SF) precisely because such stories take up the speculative limits of science, probing the fissure between fact and fiction. As Donna Haraway contends, SF novels activate an 'opening up what is yet-to-come in protean entangled times' pasts, presents, and futures' (2013: n.p.). In SF the present historical moment, with its particular sociotechnical aspect, is used as a base for extreme extrapolation, producing another world that is weirdly and shockingly possible. For Haraway, this 'opening up' is always political, and charges those who speculate with a responsibility for the worlds they bring into being, and for those who will 'bear the consequences' of the created world (Truman, 2019: 35). Carl Freedman (2000) notes that science fiction as a genre, is 'the one most devoted to the historical concreteness and the historical self-reflectiveness of critical theory' (Freedman, 2000: xvi). In speculative fiction, scientific concepts and practices are often queered or extrapolated to extremes using thought experiments and narrative devices and tropes and can help readers imagine a radically different form of empiricism (de Freitas, 2017a; de Freitas and Truman, 2020b). SF stories can put flesh on a thought experiment and do philosophy through character and story. These speculations function politically, exploring the limits of science, while tracing the links between science and society (Shaviro, 2015).

The novel The Three-Body Problem sheds considerable light on contemporary issues of dis/trust in science and mathematical modeling within a chaotic climate. The novel follows the principal character Wang Miao, a nano-technology engineer, as he learns about an alien Trisolaran world subject to a chaotic climatic regime. The Trisolarans must solve the three-body problem in order to predict the movement of their three suns, which move chaotically across their skies. The Trisolaran world lacks habitable regularity and seems to undermine the very possibility of science. The only invariants and scientific claims possible in this world are empty tautologies: 'Other than Stable Eras, all times are Chaotic Eras' (Liu, 2014: 96). Such statements may have some truth value in relation to an environment of absolute contingency, but they have no content or use-value and offer no way forward for conventional scientific method. There seems to be no pattern of solar behavior that is invariant in the Trisolaran world, and therefore no possibility for science. How can science work in such a world? In Three-Body Problem, Trisolarans are nonetheless capable of science-as-war, and stealthily attack the earth from afar, sending modified protons - named 'sophons' - to interfere at the imperceptible scale in scientific experiments on Earth. The Trisolarans hope that the sophons will undermine the replicability of the experimental method on Earth, destroy human science, and leave the earth vulnerable to invasion. Their aim is to undermine trust in science on earth, using various tactics, until scientists come to conclude that physics does not exist. 
The gravitational problem of three-bodies is a classical problem that has resisted solution over the centuries. The problem was of huge industrial importance in the $18^{\text {th }}$ century, because of its relevance to navigation and European colonial exploits. The French mathematician Henri Poincaré (1854-1912), known also for his work on global telecommunications, showed that the problem cannot be resolved using classical analysis due to the sensitivity of the system to initial conditions. In other words, there is no closed-form solution (captured in a parametric model), and we must use brute-force methods to capture the unique systemic relations in any given three-body situation. The problem has hence been considered unsolvable in the general case. There has been progress in the last decades, in what are called 'periodic' solutions using multiple computational simulations (Liao and Li, 2019). In the fictional context of The ThreeBody Problem, the main character Wang participates in various attempts to solve the problem. At one point, a solipsistic mathematician, Wei Cheng, develops an 'evolutionary algorithm' that promises to solve the problem. This computational big-data approach, relying on extractive data mining techniques rather than analytic models, also fails to help. The brute computational methods - enacted in a simulated game-world involving vast armies of binary agents - are simply not adequate to understand the chaotic system.

In a short essay called Science fiction and extro-science fiction, Meillassoux distinguishes between two regimes of fiction, SF and XSF, where SF always entails a 'fictional future of science that modifies, and often expands, its possibilities of knowledge and mastery of the real' (2015: 4-5) while XSF (or in French, fiction hors-science), is a fiction of 'worlds outside-science' (2015: 5). These latter worlds are not simply without science but are rather worlds where science is impossible. XSF is an attempt to think of a world outside science, a world that cannot be configured as an object of scientific inquiry, a world that is, in principle or in essence, inaccessible to science. Meillassoux finds that most SF fiction cannot achieve this. SF stories are always creating the possibility of science, a science that stretches the limits of our current practice. One wonders whether the engine of story itself imposes structural constraints on altworlding so strongly that invariant 'laws of nature' always emerge, and hence also science as we've come to know it. For Meillassoux, a lawless world would be without science, though not without other capacities. In other words, it would not be utter mayhem. There could be another kind of regularity, and, I would imagine, another kind of trustworthy method that comes to understand that world, achieved without reliance on classical or probabilistic science.

The existence of such a fiction (XSF) might underpin a speculative materialist project, which breaks with Kantian correlationism, so as to posit a radical outside or non-relational, which Meillassoux describes as a world ('our' world in as much as we partake) of necessary and absolute contingency. His project is to pursue a kind of speculative materialism that escapes the co-relationism that has dominated post-Kantian philosophy. Thus, XSF is meant to gesture towards a world that is not merely historically contingent, a world in which science might have mutated into a radically different and near unrecognizable science. Instead, this world would exhibit a much grander contingency that refused to be captured in some inclusive image of pluralistic science. Meillassoux is at odds with Latour here, and with many new materialists. 
When turning to speculative fiction in search of examples where there is a robust attempt to disassociate the conditions of science from the conditions of thought, we expect to find some form of inquiry incommensurable with our current scientific practice. It would be a world where irregularity would be sufficient to abolish science but not consciousness: 'A world whose margins would become capricious, but this caprice would not refer to any hidden intention' (Meillassoux, 2015: 36). This raises the question: What forms of inquiry will do justice to the trickster nature of matter? (Carstens, 2017). Would there only be one legitimate method in such a world, a method that simply aimed to chronicle things? The disorder of such a world would be so manifest that any of those who persisted in imagining a hidden law to explain the absurd variations of nature would seem 'eccentric or vain' (2015: 37).

Is The Three-Body Problem an example of XSF? Does it refuse science or all empirical inquiry? Does it 'present' an outside or alien world, replete with disorder and disunity, into which the human world is thrown, where the inherent contingency of law-like behaviour is revealed as necessary and absolute? Or does the novel simply pursue a Humanist image of science, enacting a colonial intergalactic acquisition? Initially, I had thought that The ThreeBody Problem was a good candidate for XSF, but the more I considered it, the more it seemed spot in the middle of the SF genre. Gesturing towards XSF, the novel presents a world where the laws of nature are radically altered; The quantum intervention of creating 'sophon' particles seems to gesture towards the possibility of a radically different form of inquiry (sophon being an interesting mixture of wisdom and matter). Ultimately, however, the novel retreats to a humanist image of reason. The plot presents us with a science that is technologically advanced and epistemically enhanced, but all too human in its image of reason. The science in the novel reflects historical context (i.e. The Chinese Cultural Revolution) as well as the planetary context (Earth versus Trisolaran world) and does not invest in a speculative thought and empirical inquiry that engages with absolute contingency. Despite reframing scientific practice as morethan-human and indifferent to human survival, it seems in the end that the scientific advancements - both the science performed by the Trisolarans and scientific advancements on Earth - are entirely fueled by imperialism (see de Freitas and Truman, 2020b). Much of the plot celebrates human exceptionalism and continues to invest in what both Latour and Barad have called 'causalist' interpretations of scientific intervention.

\section{Concluding gesture: All of chance}

Earthly trust in science has been fueled by a certain kind of 'belief in the world', to borrow Deleuze's (1985) refrain, and in a tradition of empiricism that has always been troubled by its own speculative tendencies. Such belief, for Deleuze, must learn to affirm 'all of chance' and not simply invest or trust in the predictive weighted outcomes of some probabilistic measure (Deleuze, 1990: 60). For a form of inquiry to affirm 'all of chance' it would have to stretch into the actual infinite of the speculative imaginary, and engage with absolute contingency; this seems a tall order. Inquiry under these bizarre conditions could not be packaged and sold as a unitary epistemological encoding of passive unified matter. It would splinter into a thousand 
practices, and there would be a fundamental disunity to inquiry methods. Belief and trust would be ground in an affirmation of a multiple earth, demanding multiple 'sciences', each enthrall to a paradoxical embrace of all of chance. As I ponder this strange world, I realize this entails accepting that science is not unified around truths, but around trusted rituals of engagement in risky forms of diplomacy.

The role of speculative thought is crucial to this image of empiricism. In addition to being the imaginative force of thinking-otherwise (Åsberg, et al., 2015), speculative thought is also the generative source of disunity in science - in other words, speculative thought breaks up the monolithic unity of science, and plugs into an ontological diversity that refuses totalizing capture. In this way, speculation multiplies the possible epistemic positions without 'reverting to relativism or constructivism' (James, 2019: 149). Significantly, following Krahg (2015), mathematics is often the speculative force pushing science outside of itself (XSF). This opens up science and mathematics to promiscuous materialisms that entail a limitless multiplicity of the real (Dupré, 1993). According to this approach, it would then be necessary to affirm the epistemological disunity of science and ontological disorder of matter and confront the contemporary science deniers who are concerned with its apparent relativism and changing consensus.

Speculative fictions like The Three-Body Problem help us to grasp the deeply complex nature of empirical inquiry - a practice that typically involves land grabs and colonial conquest, diplomacy, betrayal, and speculative ontogenerative interventions. If future empiricisms are to expand alliances across posthuman ecologies, while still invested in imperial world building, we must maintain a skepticism and even a certain capacity for betrayal of the ideals or disciplines that established the conditions for these forms of inquiry. Surely the ethics of such future practices will involve responding to the emergent dependency relations in the metamorphic zone, so that forms of inquiry will expand sensitivities and increase our comprehension of the abstract work of chance and contingency. In living with the possibility of such betrayal, and 'staying with the trouble' as Haraway (2016) reminds us, science as a risky speculative activity has the potential to proliferate agencies in a pluralistic and potentially more inclusive future. The plot and poetics of speculative fiction novels like The Three-Body Problem immerse us as readers into strange and estranged relational ontologies. SF stories force us to grapple with the outside of science. And they show the power of speculative thought - as promiscuous venture - transgressing the borders of necessity and sufficiency and engaging in creative contingencies.

\section{Author Biography}

Elizabeth de Freitas is a Professor in the Education and Social Research Institute and co-director of The Manifold Laboratory for Biosocial \& Eco-Sensory Research on Learning and Behavior, at Manchester Metropolitan University. Her research focuses on philosophical investigations of mathematics, science and technology, pursuing the implications and applications of this work across the social sciences. Her research has been funded by the Canada Council for the Arts, 
the U.S. National Science Foundation, and the Social Sciences and Humanities Research Council of Canada. She has published 3 books and over 50 chapters and articles.

\section{References}

Alumkal, A. 2017. Paranoid Science: The Christian Right's War on Reality. New York: New York University Press.

Åsberg, C. Thiele, K. \& van der Tuin, I., 2015. Speculative before the turn: Reintroducing feminist materialist performativity. Cultural Studies Review, 21 (2): 145-172.

Bahng, A. 2017. Plasmoidial improprieties: Octavia E. Butler, Slime molds, and imagining a Femi-Queer commons. In Cipolla, Cyd., Gupta, K., Rubin, D.A. \& Willey, A. (eds.) Queer Feminist Science Studies. Washington: University of Washington Press, 310-326.

Barnes, E. 1997. States of Sympathy: Seduction and Democracy in the American Novel. Columbia: Columbia University Press.

Blake, A. 2015. Americans increasing distrust in science - and not just in climate change. The Washington Post, 30 January. Available at: https://www.washingtonpost.com/news/thefix/wp/2015/01/30/americans-increasing-distrust-of-science-and-not-just-on-climatechange/ (accessed 21 September 2020).

Butler, O. 2000. Lilith's Brood. 2000. New York, NY: Grand Central Publishing.

Carstens, D. 2017. Tricksters, animals, new materialities and indigenous wisdoms. In Woodward, W. \& McHugh, S. (eds.) Indigenous Creatures, Native Knowledges, and The Arts: Animal Studies in Modern Worlds. Cham, Switzerland: Palgrave, 93-115.

Chakrabarty, D. 2009. The climate of history: Four theses. Critical Inquiry, 35(2): 197-222.

Chakrabarty, D. 2012. Postcolonial studies and the challenge of climate change. New Literary History, 43(1): 1-18.

Chakrabarty, D. 2014. Climate and capitalism: On conjoined histories. Critical Inquiry, 42(1): 123.

Colebrook, C. 2019a. A cut in relationality: Art at the end of the world. Angelaki: Journal of the Theoretical Humanities, 24(3).

Colebrook, C. 2019b. Unthinkable extinction: Cinematic time and the panorama of history. Alienocene: Journal of the First Outernation. Available at https://alienocene.com/2019/06/19/unthinkable-extinction/ (accessed 23 September 2020).

Danowski, D. \& Viveiros de Castro, E. 2017. The Ends of the World. Cambridge: Polity.

Deleuze, G. 1985. Cinema II: The Time Image, trans. H. Tomlinson \& R. Galeta. London: Bloomsbury Press.

Deleuze, G. 1990. Logic of Sense, trans. M. Lester \& C. Stivale. Columbia: Columbia University Press.

Drummond, C. \& Fischhoff, B. 2017. Individuals with greater science literacy and education have more polarized beliefs on controversial science topics. Proceedings of the National Academy of Sciences, 114(36): 9587-9592. 
Faulkner, P. \& Simpson, T., 2017. The Philosophy of Trust. Oxford: Oxford University Press.

Freedman, C. 2000. Critical Theory and Science Fiction. Hanover: Wesleyan University Press.

de Freitas, E. 2019. Invited lecture. Bruno Latour and distrust in science. The Royal Society for Philosophy, Human Sciences Seminar Series, Manchester Metropolitan University, February.

de Freitas, E. 2017. Non-human findings from the laboratory of speculative sociology. Minnesota Review, 88: 116-126

de Freitas, E. 2020. Science studies and the metamorphic multiple earth: Risky diplomacies in the end-times. Cultural Studies $\leftrightarrow$ Critical Methodologies, 20(3): 203-212.

de Freitas, E. \& Weaver, J. 2020. Rethinking social inquiry in the wake of science studies: Transdiscipline pursuits in times of climate change, information flows, and fading democracies. Cultural studies $\leftrightarrow$ Critical Methodologies, 20(3): 195-202.

de Freitas, E. \& Truman, S. 2020a. New empiricisms in the Anthropocene: Thinking with speculative fiction about science and social inquiry. Qualitative Inquiry. DOI: https://doi.org/10.1177/1077800420943643

de Freitas, E. \& Truman, S. 2020b. Science fiction and science dis/trust: Thinking with Bruno Latour's Gaia and Liu Cixin's The Three-Body Problem. Rhizomes: Cultural Studies in Emerging Knowledge, 36.

Dubré, J. 2003. The Disorder of Things: The Metaphysical Foundations of the Disunity of Science. Cambridge, US: Harvard University Press.

Funk, C., Hefferon, M., Kennedy, B., Johnson, C. 2019. Trust and mistrust in Americans views of scientific experts. Pew Research Center: Science and Society. https://www.pewresearch.org/science/2019/08/02/trust-and-mistrust-in-americansviews-of-scientific-experts/ (accessed 21 September 2020).

Gauchat, G. 2012. Politicization of science in the public sphere: A study of public trust in the United States, 1974 to 2010. American Sociological Review, 77(2): 167-187.

Hansson, S. 2017. Science denial as a form of pseudoscience. Studies in History and Philosophy of Science Part A, 63: 39-47.

Haraway, D. 2013. SF: Science Fiction, Speculative Fabulation, String Figures, So Far. Ada: $A$ Journal of Gender, New Media, and Technology, 3. https://adanewmedia.org/2013/11/issue3-haraway/ (accessed 21 September 2020).

Haraway, D. 2016. Staying with the Trouble: Making Kin in the Chthulucene. Durham, NC: Duke University Press.

Hossenfelder, S. 2017. Lost in Math: How Beauty Leads Physics Astray. NY: Hachett Book Group. James, I. 2019. The Technique of Thought: Nancy, Laruelle, Malabou and Stenger after Naturalism. Minnesota: University of Minnesota Press.

Kragh, H. 2015. Fundamental theories and epistemic shifts: Can history of science serve as a guide? Paper presented at the conference: Why trust a theory? Reconsidering scientific methodology in light of modern physics. Available at https://videoonline.edu.Imu.de/en/node/7481 (accessed 23 September 2020). 
Keeling, K. 2019. Queer Times, Black Futures. New York, NY: New York University Press.

Ladyman, J. \& Ross, D. 2007. Every Thing Must Go. Oxford: Oxford University Press.

Latour, B. 2010. Tarde's idea of quantification. In M. Candea (Ed.), The social afer Gabrielle Tarde: Debates and assessments. 147-164. New York, NY: Routledge.

Latour, B. 2015. Diplomacy in the Face of Gaia: Bruno Latour in conversation with Heather Davis. In Davis, H. \& Turpin, E. (ed.) Art in the Anthropocene: Encounters among Aesthetics, Politics, Environments and Epistemologies. London: Open Humanities Press.

Latour, B., 2017. Facing Gaia: Eight Lectures on the New Climatic Regime. Oxford: Polity Press.

Latour, B., 2018. Down to Earth. Oxford: Polity Press.

Lewandowsky, S., Gignac, G.E. \& Oberauer, K. 2013. The Role of Conspiracist Ideation and Worldviews in Predicting Rejection of Science. PLOS ONE, 8(10): e75637.

Lewandowsky, S. \& Oberauer, K. 2016. Motivated rejection of science. Current Directions in Psychological Science, 25: 217-222.

Li, G. \& Isaacson, N. 2019. China turns outward: On the literary significance of Liu Cixin's science fiction. Science-Fiction Studies.

Liao, S. \& Li, X. 2019. On the periodic solutions of the three-body problem. National Science Review, 6(6): 1070-1071.

Liu, C. 2014. The Three-Body Problem. New York: Tor.

Lothian, A. 2018. Old Futures: Speculative Fiction and Queer Possibility. New York: New York University Press.

Meillassoux, Q. 2015. Science Fiction and Extro-Science Fiction. Minnesota: University of Minnesota Press.

Melillo, J.M., Richmond, T. \& Yohe, G. (eds.) 2014. Climate Change Impacts in the United States: The Third National Climate Assessment. U.S. Global Change Research Program. DOI: 10.7930/J0Z31WJ2.

Mooney, C. 2005. The Republican War on Science. New York: Basic Books.

National Opinion Research Center at the University of Chicago, 2018. US General Social Survey.

National Science Teaching Association, 2018. NSTA Position Statement on The Teaching of Climate Science. National Science Teaching Association.

Nature Editorial, 2017. Beware the anti-science label. Nature, 545: 133-134.

Oreskes, N. 2019. Why Trust Science. New Jersey: Princeton University Press

Pittinsky, T. 2015. America's crisis of faith in science. Science, 348: 511-512.

Rieder, J. 2008. Colonialism and the Emergence of Science Fiction. Middletown: Wesleyan University Press.

Rutjens, B., Sutton, R. \& van der Lee, R. 2017. Not All Skepticism Is Equal: Exploring the Ideological Antecedents of Science Acceptance and Rejection. Personality and Social Psychology Bulletin, 44 (3): 384-405.

Schuller, K. 2018. The Biopolitics of Feeling: Race, Sex and Science in the $19^{\text {th }}$ Century. Durham: Duke University Press.

Shaviro, S. 2015. Discognition. London: Repeater. 
Sinclair, N., de Freitas, E. \& Ferrara, F. 2013. Virtual encounters: The murky and furtive world of mathematical inventiveness. ZDM - The International Journal of Mathematics Education, 45(2); 239-252.

Stengers, I. 2018. Another Science is Possible: A Manifesto for Slow Science. Cambridge: Polity Press.

Subramaniam, B. 2014. Ghost Stories for Darwin: The Science of Variation and the Politics of Diversity. Illinois: University of Illinois Press.

Truman, S.E. 2019. SF! Haraway's Situated Feminisms and Speculative Fabulations in English Class. Studies in Philosophy and Education, 38(1).

Tsing, A. 2015. The Mushroom at the End of the World: On the Possibility of Life in Capitalist Ruins. Princeton, NJ: Princeton University Press.

Wark, M. 2017. Bruno Latour: Occupy Earth. Verso Blog, 5 October. Available at https://www.versobooks.com/blogs/3425-bruno-latour-occupy-earth (accessed 23 September 2020).

Yusoff, K. 2018. A Billion Black Anthropocenes or None. Minnesota: University of Minnesota Press. 